Dr. sc. Damir Primorac, izvanredni profesor

Sveučilišni odjel za forenzične znanosti Sveučilišta u Splitu, Marko Pilić, mag. forens.

Sveučilišni odjel za forenzične znanosti Sveučilišta u Splitu

\title{
SIGURNOST I ZAŠTITA NA NOGOMETNIM UTAKMICAMA I OSTALIM SPORTSKIM PRIREDBAMA PREMA RJEŠENJIMA KONVENCIJE VIJEĆA EUROPE CETS BR. 218
}

\author{
UDK: $343 / 344$ 706/799 \\ Primljeno: 20. 01. 2019. \\ Izvorni znanstveni rad
}

Potaknuto nasilničkim ponašanjima određenih nogometnih navijača u Bruxellesu na stadionu Heysel 29. svibnja 1985. godine, Vijeće Europe donijelo je Europsku konvenciju o nasilju i nedoličnom ponašanju gledatelja na športskim priredbama, posebice na nogometnim utakmicama (CETS br. 120), tzv. Konvenciju br. 120, koja je stupila na snagu 1. studenoga 1985. godine. Konvencija br. 120 zadržala je svoja izvorna obilježja sve do 2013. godine kada je Odbor ministara Vijeća Europe zaključio da je zastarjela i da nije usklađena s iskustvima stečenima od prvotnog stupanja na snagu iste Konvencije. Sukladno tome, Stalni odbor odlučio je izraditi novi tekst Konvencije i kao rezultat toga nastala je Konvencija Vijeća Europe o integriranom pristupu sigurnosti, zaštiti i uslugama na nogometnim utakmicama i drugim športskim priredbama (CETS br. 218), tzv. Konvencija br. 218. Sigurnosne mjere, mjere zaštite i mjere u području usluga, kao ključni dio Konvencije br. 218, imaju za cilj stvoriti sigurno i zaštićeno okruženje na svim športskim priredbama. Integrirani pristup sigurnosti zahtijeva koordinaciju na međunarodnoj, nacionalnoj i lokalnoj razini te je naglašena važnost učinkovite suradnje s policijom, hitnim službama, kao i ostalim partnerima, ne samo u pogledu jamčenja tjelesne sigurnosti, već i u sprečavanju diskriminirajućeg i rasističkog ponašanja. Utvrđena je i važnost osnivanja nacionalne nogometne informacijske točke kao ključnog posrednika u razmjeni informacija i podataka o nogometnim utakmicama s međunarodnim predznakom kao i za međunarodnu suradnju državnih tijela bitnih za sigurnost na nogometnim utakmicama. Razlozi nastajanja Konvencije br. 218 nisu samo u sprečavanju nasilničkog ponašanja na športskim priredbama i poboljšanje sigurnosti i zaštite, već i daljnji razvitak te bolja koordinacija međunarodne suradnje u pogledu kaznenog progona počinitelja takvih delikata.

Ključne riječi: sigurnost, zaštita, sportske priredbe, nasilničko ponašanje 


\section{UVOD}

U današnje vrijeme nasilje, na žalost, egzistira u skoro svim pojavnim oblicima društva. Kao takvo, može se identificirati u obitelji, na ulici, kao etničko i kulturalno nasilje pa tako i na športskim natjecanjima. ${ }^{1}$ Kada je riječ o nasilju na športskim natjecanjima, ono što je zabrinjavajuće jest da se povremeno intenzivira te dovodi do ostvarivanja najgorih mogućih scenarija odnosno stradavanja nedužnih promatrača. Iako nasilje u sportu ne predstavlja novost te je prisutno još od antičkoga doba, ${ }^{2}$ ipak ekstremizam, vandalizam i huliganizam te vrste treba kontrolirati ako ga se već ne može u potpunosti iskorijeniti. To podrazumijeva kontrolu rizika od strane odgovornih tijela, ponajprije policije, i njihovo proaktivno djelovanje. ${ }^{3}$ Sve to nametnulo je određivanje pravnih okvira reguliranja ponašanja na športskim priredbama kako bi se spriječilo i sankcioniralo neželjeno ponašanje potencijalnih izgrednika te povećala sigurnost i zaštita gledatelja na stadionima. ${ }^{4}$ Prošlost pamti mnoge neželjene događaje na športskim priredbama, a pogotovo na nogometnim utakmicama.

Zanimljivo je napomenuti kako prvi zabilježeni incident nije bio na nogometnoj utakmici već na utakmici kriketa u Australiji, a događaj je ostao upamćen kao buna u Sydneyu kada je 2000 gledatelja ušlo na teren i prekinulo igru zbog nezadovoljstva jednom sudačkom odlukom. Taj događaj datira još iz 1879. godine. ${ }^{5}$ Jedan od najzapamćenijih ozloglašenih događaja zbio se još 1985 . godine kada je tijekom nasilnih sukoba na stadionu Heysel u Bruxellesu poginulo 39 ljudi, a još stotine su ozlijeđene. ${ }^{6}$ Heysel nije izolirani slučaj, primjera nasilja na športskim stadionima ima mnoštvo; za vrijeme utakmice PSG-a i Caena 1993. godine pretučeni su policajci na tribinama; 1998. godine za vrijeme Svjetskog prvenstva u Francuskoj u Lensu, ispred stadiona, pretučen je žandar. Dugo će se pamtiti i neprimjereni postupci sportaša na športskim priredbama, a možda i najpoznatiji nasilni ispad francuskog nogometaša Erica Cantone koji je u to vrijeme branio boje Manchester Uniteda te početkom 1995. godine neprimjereno reagirao na provokaciju jednog navijača protivničkog kluba odnosno preskočio zaštitnu barijeru i navijača udario nogom u prsa. Takve reakcije sportaša nisu novost niti u najboljoj američkoj košarkaškoj ligi; u veljači 1995. godine na utakmici između Portland Trail Blazersa i Houston Rocketsa,

\footnotetext{
1 Jovašević, D., Batrićević, A., „Suppression of spectator violence at sports events“, Facta Universitatis, Srbija, Physical Education \& Sport, 11 (3). str. 21.

Bodin, D., Robene, L., Heas, S., Sport i nasilje u Europi, Knjiga trgovina d.o.o., Zagreb, 2007.,

3 Tsoukala A., Football Hooliganism in Europe - Security and Civil Liberties in the Balance, 2009., Palgrave Macmillan, England, str. 7.

4 Nimac, K., „Sprječavanje nereda na športskim natjecanjima - Zakonska regulativa u Republici Hrvatskoj i nekim europskim zemljama“, Zbornik radova Veleučilišta u Šibeniku, No. 3-4, Šibenik, 2016. str. 119.

5 Više vidi na: https://www.sportskeeda.com/cricket/cricket-history-the-sydney-riot-1879.

6 Prijedlog Odluke Vijeća o ovlašćivanju država članica da postanu stranke, u interesu Europske unije, Konvencije Vijeća Europe o integriranom pristupu sigurnosti, zaštiti i uslugama na nogometnim utakmicama i drugim športskim priredbama (CETS. br. 218), Bruxelles, 2018.
} 
košarkaš Houstona Vernon Maxwell pretrčao je desetak redova na tribinama i krenuo udarati jednog navijača, navodno isprovociran njegovim dobacivanjem na račun svoje obitelji. ${ }^{7}$ Također, rasizam i ksenofobija su, na žalost, česti slučaj prilikom odigravanja nogometnih utakmica diljem Europe. ${ }^{8}$ Možda i najučestalije rasističke napade proživljavao je nogometaš Mario Balotelli po stadionima u Italiji i Engleskoj. Najrecentniji je primjer i slučaj Raheema Sterlinga kojega su četvorica navijača protivničkog kluba, Chelseae iz Londona, vrijeđala na rasističkoj razini u prosincu 2018. godine. Pozitivan primjer u tom slučaju bila je reakcija londonskoga kluba koji je ukinuo godišnje pretplate četvorici izgrednika, a jedan od njih je u međuvremenu izgubio i stalan posao zbog svog ponašanja na nogometnoj utakmici. Nakon incidenta u Bruxellesu na stadionu Heysell, Europa je morala reagirati i to je učinila tako da je donijela Konvenciju o nasilju i nedoličnom ponašanju gledatelja na športskim priredbama, posebice na nogometnim utakmicama, a zamijenila ju je nedavno Konvencija Vijeća Europe o integriranom pristupu sigurnosti, zaštiti i uslugama na nogometnim utakmicama i drugim športskim priredbama.

\section{EUROPSKA KONVENCIJA O NASILJU I NEDOLIČNOM PONAŠANJU GLEDATELJA NA ŠPORTSKIM PRIREDBAMA, POSEBICE NA NOGOMETNIM UTAKMICAMA (CETS BR. 120)}

Konvencija o nasilju i nedoličnom ponašanju gledatelja na športskim priredbama, posebice na nogometnim utakmicama (dalje u tekstu: Konvencija br. 120$)^{9}$ imala je za cilj jedinstvo i zajedništvo država članica Europske unije (dalje u tekstu: države članice) u borbi protiv nasilja i nedoličnog ponašanja na športskim priredbama $s$ naglaskom na važnost doprinosa u razumijevanju sporta općenito, ali i nogometnih utakmica, kako na nacionalnoj, tako i na europskoj razini. Ujedno, cilj Konvencije br. 120 bio je implementirati sve potrebne mjere u zakonodavne okvire država članica kako bi se spriječila i nadzirala protupravna ponašanja na športskim priredbama, ${ }^{10}$ a potpisnice su se obvezale da će poduzeti sve potrebne mjere kako bi spriječile i suzbile nasilje i protupravno ponašanje sukladno, između ostalog, i člancima 3.-6. ove konvencije. ${ }^{11}$ Iako su tijela javne vlasti i neovisne sportske organizacije razdvojene u svom radu i obnašanju funkcija, u kontekstu ove konvencije imaju dodirne točke u kojima dijele odgovornost i zasluge u borbi protiv nasilja i nedoličnog ponašanja

7 Vidi više na: The Daily Iowan - Iowa City, Iowa; http://dailyiowan.lib.uiowa.edu/DI/1995/di199502-08.pdf, str. 4B, 8. veljače 1995. godine.

8 Bodin, D., et. al., op. cit., str. 19.

9 Europska konvencija o nasilju i nedoličnom ponašanju gledatelja na športskim priredbama, posebice na nogometnim utakmicama (engl. European Convention on Spectator Violence and Misbehaviour at Sports Events and in particular at Football Matches), donesena u Strasbourgu 19. kolovoza 1985. godine, a stupila na snagu 1. studenoga 1985. godine.

10 Primorac, D., Duvnjak, Ž., Roso, S., ,Neki aspekti prekršaja prema zakonu o sprječavanju nereda na športskim natjecanjima“, Zbornik radova Pravnog fakulteta u Splitu, god. 47, 2, Split, 2010., str. 337.

11 Šuput D., „Pravni okvir koji uređuje borbu protiv nasilja na sportskim priredbama u evropskim državama“", Strani pravni život, Beograd, 2010., str. 237. 
gledatelja te su zajednička i koordinirana djelovanja označena kao ključ u kontroli i prevenciji nasilja na športskim priredbama. ${ }^{12}$ Stranke Konvencije br. 120 trebale su se pobrinuti osigurati dovoljno resursa, financijskih i ljudskih, kao reakciju na eventualno nasilno i nedolično ponašanje, odnosno poticati suradnju svih važnih tijela u tom procesu, prvenstveno u razmjeni ključnih informacija što bi dovelo do anticipacije izgreda i pravovremenog djelovanja. ${ }^{13}$ Također, jedna od ključnih mjera u navedenoj konvenciji bilo je prihvaćanje pravnog okvira o primjerenim kaznama za počinitelje protupravnih radnji nasilnog i nedoličnog ponašanja. ${ }^{14}$ Za potrebe ove konvencije formirana je Stalna komisija u kojoj je svaka stranka konvencije imala barem jednog predstavnika, dok su države članice Vijeća Europe ili stranke Europske kulturne konvencije, a nisu stranke Konvencije br. 120, mogle imati predstavnika, ali samo u statusu promatrača. ${ }^{15}$ Stalna komisija, u okviru ove konvencije, bila je nadležna za nadgledanje njezine primjene, kao i za razmatranje eventualnih potreba izmjena konvencije, obavljanje konzultacija s nadležnim športskim agencijama, preporučivanje odgovarajućih mjera strankama konvencije, pružanje prijedloga za poboljšanje učinkovitosti te davanje preporuka Komisiji ministara o pristupanju država koje nisu članice Vijeća Europe Konvenciji br. 120.

Republika Hrvatska (dalje u tekstu: RH) 27. siječnja 1993. godine ratificirala je ovu konvenciju, a ona je stupila na snagu 1. ožujka 1993. godine. Konvencija br. 120 poslužila je kao temelj RH u donošenju Zakona o sprečavanju nereda na športskim natjecanjima (dalje u tekstu: ZSNŠN) ${ }^{16} 2003$. godine s tim da je od tada zakonodavac napravio tri izmjene i dopune ZSNSN-a koje su imale za cilj smanjiti broj izgreda na stadionima, pooštriti sankcije te propisno opremiti športske objekte. Sukladno ZSNŠN-u, za športske priredbe odnosno natjecanja smatraju se sva natjecanja koja su organizirana u okviru sustava športskog natjecanja gdje postoje domaći i gostujući klub odnosno međunarodno natjecanje organizirano na području $\mathrm{RH} .{ }^{17}$ Kao uzrok nedoličnog ponašanja na športskim natjecanjima često je konzumiranje alkoholnih pića, ali i posjedovanje i upotrebljavanje pirotehničkih sredstava te je kao takvo predstavljalo predmet suočavanja tijela vlasti s počiniteljima tih vrsta izgreda, što je nakon početka primjene ZSNSN-a dovelo do smanjenja već navedenih protupravnih ponašanja. ${ }^{18} \mathrm{U}$ tom kontekstu zanimljiv je i pristup država članica koje su se uhvatile u koštac s rješavanjem problema nasilja na nogometnim utakmicama. $\mathrm{S}$ jedne strane imamo primjer Velike Britanije koja je primijenila reaktivni pristup

12 Čl. 2. Konvencije br. 120.

13 Čl. 3. st. 1. toč. a., b. Konvencije br. 120.

14 C̆l. 5. Konvencije br. 120.

15 C̆l. 8. Konvencije br. 120.

16 Zakon o sprječavanju nereda na športskim natjecanjima (NN br. 117/03, 71/06, 43/09, 34/11).

17 Margetić, M., Borovec, K., „Zakon o sprječavanju nereda na športskim natjecanjima - preventivne i represivne mjere sudova i policije“, Hrvatski ljetopis za kazneno pravo i praksu, vol. 22, broj 2, Zagreb, 2015., str. 594.

18 Primorac, D., Konjić, Z., Blaće, K., „Kaznena djela u zakonu o sprječavanju nereda na športskim natjecanjima s osvrtom na mjere opreza prema zakonu o kaznenom postupku“, Zbornik radova Pravnog fakulteta u Splitu, god. 48, 4, Split, 2011., str. 828. 
u smislu poboljšanja policijskog nadzora i tehnika djelovanja, segregacije navijača, restrikcije na konzumaciji alkoholnih pića, ali i u zakonodavnom smislu gdje je donesen niz zakona i odredbi o nedoličnom ponašanju navijača na nogometnim utakmicama. ${ }^{19} \mathrm{~S}$ druge pak strane, vidljivi su primjeri drugih država članica odnosno Njemačke, Nizozemske i Belgije koje su primijenile proaktivni pristup rješavanju problema huliganizma i to na način da provode tzv. „fan coaching“" odnosno aktivnu suradnju i komunikaciju čelnika klubova s grupama navijača. ${ }^{20}$

\section{KONVENCIJA VIJEĆA EUROPE O INTEGRIRANOM PRISTUPU SIGURNOSTI, ZAŠTITI I USLUGAMA NA NOGOMETNIM UTAKMICAMA I DRUGIM ŠPORTSKIM PRIREDBAMA (CETS. BR. 218)}

Studija o potrebi ažuriranja Konvencije br. 120 rezultirala je nužnosti revidiranja iste sukladno iskustvima i praksom te je u prosincu 2013. godine Komisija ministara Vijeća Europe donijela odluku, ne o ažuriranju postojeće konvencije, već o izradi sasvim novog dokumenta koji će biti usklađen s dobrom praksom i najnovijim preporukama Stalne komisije. ${ }^{21}$ Rezultat toga jest donošenje Konvencije Vijeća Europe o integriranom pristupu sigurnosti, zaštiti i uslugama na nogometnim utakmicama i drugim športskim priredbama (dalje u tekstu: Konvencija br. 218)22 koja je usklađena s politikom djelovanja Europske unije (dalje u tekstu: EU) po pitanju osiguravanja sigurnosti, zaštite i usluga u športu, ${ }^{23}$ ali i kao dio politike suradnje država članica s trećim zemljama u području sporta i obrazovanja. ${ }^{24} \mathrm{Cilj}$ je Konvencije br. 218 omogućiti sigurnost, zaštitu i kvalitetnu uslugu ponajviše na nogometnim utakmicama, ali i na ostalim športskim priredbama prvenstveno kroz integraciju multiagencijskog pristupa u osiguranju navedenih elemenata, kao i aktivan pristup prema suradnji odgovornih lokalnih, nacionalnih i međunarodnih tijela.

Prvi korak u tom smjeru jest nastojanje na tome da nadležna tijela spoznaju kako sigurnost, zaštita i usluge nisu odvojene komponente već ih treba promatrati kao tri međusobno zavisna dijela koja zajedno tvore cjelinu čijim se kvalitetnim provođenjem

19 Više o tome vidi na: https://www.legislation.gov.uk/ukpga/1989/37.

20 Vidi više na: http://www.sirc.org/publik/fvexec.html\#_VPID_8.

21 Prijedlog Odluke Vijeća o ovlašćivanju država članica da postanu stranke, u interesu Europske unije, Konvencije Vijeća Europe o integriranom pristupu sigurnosti, zaštiti i uslugama na nogometnim utakmicama i drugim športskim priredbama (CETS. br. 218), Bruxelles, 2018., str. 1.

22 Konvencije Vijeća Europe o integriranom pristupu sigurnosti, zaštiti i uslugama na nogometnim utakmicama i drugim športskim priredbama (engl. Convention on an Integrated Safety, Security, and Service Approach at Football Matches and Other Sports Events) koja je otvorena za potpisivanje od 3. srpnja 2016. godine u Saint-Denisu, a stupila na snagu 1. studenoga 2017. godine.

${ }^{23}$ Čl. 87. Ugovora o funkcioniranju Europske unije (UFEU).

${ }_{24}$ Čl. 165. st. 3. UFEU-a. 
dolazi do željenih rezultata. ${ }^{25}$ Isto tako možemo ustvrditi kako je i jedan od ciljeva Konvencije br. 218 transformirati stranke ove konvencije u kvalitetne „platforme“ za domaća odgovorna tijela u smislu uspostave nacionalnih i lokalnih koordinacijskih mjera u svrhu identifikacije, analize i procjene rizika za sigurnost, zaštitu i usluge na nogometnim i ostalim športskim priredbama što podrazumijeva i odgovarajući zakonski, regulatorni ili upravni okvir kako bi se poslala jasna poruka odgovarajućim tijelima o njihovoj ulozi. ${ }^{26}$ Te uloge uključuju, između ostalog, stvaranje sigurnog i zaštićenog okružja za sve nazočne, osiguravanje učinkovitosti licenciranja samih objekata na kojim se održava športska priredba, kvalitetno „,upravljanje masama“, ${ }^{27}$ osiguravanje kvalitetne infrastrukture i koncepta stadiona te kvalitetnu povezanost između nadležnih tijela, posebno u slučaju pojave opasnosti za gledatelje upotrebom pirotehnike, pojavom nasilnog, rasističkog ili drugog diskriminatornog ponašanja. ${ }^{28}$ Kada su u pitanju sigurnost, zaštita i usluga na javnim mjestima, nužnost je da sve uključene agencije, ali i sudionici športskih priredbi, zajedno sudjeluju u procjeni rizika i pripremanju preventivnih mjera te stvaranju sigurnog okružja na javnim mjestima, prije i poslije održavanja priredbe. ${ }^{29}$ Važnost planiranja u slučaju nužde ili hitnih intervencija naglašena je u čl. 7 Konvencije br. 218 na način da „stranke osiguravaju izradu multiagencijskih planova za slučaj nužde $i$ hitne intervencije te testiranje i poboljšanje tih planova tijekom redovitih zajedničkih vježbi. Nacionalni zakonski, regulatorni ili upravni okviri jasno određuju koja je agencija odgovorna za pokretanje, nadzor i ocjenjivanje vježbi. “”

Nadalje, velika je važnost stavljena i na građenje kvalitetnih odnosa s navijačima i lokalnim zajednicama na način da se redovito komunicira s predstavnicima navijača i lokalnih zajednica kako bi to dovelo do pozitivne suradnje i sprečavanja izgreda. ${ }^{30}$ Međunarodna razmjena informacija, ali i iskustva, nužna je za izradu i poboljšanje policijskih strategija čije operacije moraju biti u skladu s praksom i pojavnim oblicima nedoličnog ponašanja na športskim priredbama. Stranke Konvencije br. 218 moraju osigurati da policija, u svrhu omogućavanja sigurnosti, zaštite i usluga, djeluje zajedno s organizatorima, navijačima i svim ostalim sudionicima športskih priredbi. ${ }^{31}$ Naravno, stranke moraju osigurati i zakonodavno regulirati učinkovite mjere za sprečavanje i sankcioniranje kažnjivog ponašanja te jednako tako mogu tražiti od drugih stranaka ove konvencije da počiniteljima kaznenih djela na području druge države stranke izreknu odgovarajuće kazne ili u inozemstvu ili u domicilnoj državi. Za razliku od Konvencije br. 120 kojom se osnovala Stalna

25 Čl. 2. Konvencije 218 .

26 Čl. 4. Konvencije br. 218.

27 Crowd management - učinkovito upravljanje masom govori o upravljanju očekivanim i neočekivanim pojavama u većoj gužvi. Kontrola gužve može uključivati privatno angažirane čuvare, kao i policijske službenike. Sustav upravljanja masom često se koristi na velikim javnim skupovima poput uličnih sajmova, glazbenih festivala, stadiona i javnih demonstracija.

28 Čl. 5. Konvencije br. 218.

29 Čl. 6. Konvencije br. 218.

30 Čl. 8. Konvencije br. 218.

31 Čl. 9. Konvencije br. 218. 
komisija, između ostaloga nadležna i za nadgledanje primjene iste, Konvencijom br. 218 osnovan je Odbor za sigurnost i zaštitu na športskim priredbama (dalje u tekstu: Odbor). ${ }^{32}$ Države stranke mogu imati jednog ili više delegata, ali ti delegati moraju predstavljati glavne državne agencije. ${ }^{33}$ Također, osnivanjem Odbora predviđena su i mjesta za države promatračice koje mogu biti sve države članice Vijeća Europe ili države stranke Europske kulturne konvencije, a koje nisu stranke Konvencije br. 218, kao i svaka država nečlanica koja je stranka Konvencije br. 120. Konvencijom br. 218 također se propisuje i osnivanje ili imenovanje Nacionalne nogometne informacijske točke (dalje u tekstu: NFIP) unutar policije kao izravne i jedinstvene kontaktne točke za razmjenu informacija u vezi s nogometnim utakmicama međunarodnog značaja kako bi se jednostavnije koordinirala i organizirala provedba međunarodne policijske suradnje kada su u pitanju nogometne utakmice. ${ }^{34}$

S obzirom na to da Konvencijom br. 120 osnivanje iste nije bilo propisano, a pokazalo se iznimno učinkovito u državama članicama koje su je osnovale, ukazala se potreba za osnivanjem i u zemljama članicama Vijeća Europe. ${ }^{35}$ Uspostava NFIP-a temelji se na Odluci Vijeća od 25. travnja 2002. godine o sigurnosti u vezi s nogometnim utakmicama s međunarodnim elementom (dalje u tekstu: Odluka) gdje se poziva na članak 29. Ugovora o Europskoj uniji u vezi s osiguranjem visoke razine sigurnosti u području slobode, sigurnosti i pravde iz razloga što zbog velikog broja međunarodnih i europskih natjecanja te navijača koji posjećuju takve događaje, nogomet dobiva međunarodnu važnost tako da sigurnost mora biti na visokoj razini. ${ }^{36}$ Kao dodatak tom dokumentu može se smatrati i Priručnik s preporukama za međunarodnu policijsku suradnju koji detaljno obrađuje elemente djelovanja pri osiguravanju sigurnosti na nogometnim utakmicama $\mathrm{s}$ međunarodnim elementom. ${ }^{37}$ Svrha osnivanja NFIP-a, što je ovom Odlukom, kao i Konvencijom br. 218, postalo nužnost, u razmjeni je važnih informacija između policija na međunarodnoj razini. U tom kontekstu NFIP poprima ovlasti u području koordiniranja i prijenosa informacija, ne samo u međunarodnoj policijskoj suradnji, već i s ostalim agencijama odgovornima za omogućavanje sigurnosti, zaštite i usluga na nogometnim utakmicama i ostalim športskim priredbama. U međusobnoj komunikaciji NFIP-a država članica, nužnost je i procjena potencijalnih rizika koje

32 Funkcije Odbora sukladno čl. 14 Konvencije br. 218 su: „a) preispitivati odredbe ove Konvencije te razmatrati sve nužne izmjene; b) održavati konzultacije te, prema potrebi, razmjenjivati informacije s relevantnim organizacijama; c) upućivati preporuke strankama ove Konvencije o mjerama koje je potrebno poduzeti za njezinu provedbu; d) preporučivati odgovarajuće mjere kako bi javnost bila informirana o aktivnostima poduzetima u okviru ove Konvencije; e) upućivati preporuke Odboru ministara o državama nečlanicama Vijeća Europe koje se pozivaju da pristupe ovoj Konvenciji; f) ponuditi svaki prijedlog za poboljšanje učinkovitosti ove Konvencije; g) olakšavati prikupljanje, analizu i razmjenu informacija, iskustva i dobrih praksi između država."

33 Čl. 13. Konvencije br. 218.

34 Čl. 11. Konvencije br. 218.

35 Za razliku od Europske unije koja broji 28 država članica, Vijeće Europe broji 47 država članica.

36 Vidi više: Odluka Vijeća od 25. travnja 2002. o sigurnosti u vezi s nogometnim utakmicama s međunarodnim elementom (2002/348/PUP).

37 Vidi više u SL EU, 2013., Područje slobode, sigurnosti i pravde, Svezak 003, str. 80-83, dostupno na: https://eur-lex.europa.eu/legal-content/HR/TXT/PDF/?uri=DD:19:003:FULL:HR\&from=HR. 
predstavljaju klubovi vlastite države, ali i nacionalne reprezentacije. Razmjena informacija može se podijeliti u tri glavne skupine: strateške, operativne i taktičke informacije. Strateške informacije sadrže sve moguće aspekte koji mogu imati utjecaj na sigurnost, operativne informacije daju tijek postupanja prilikom događaja, a taktičke informacije omogućuju da svi uključeni u trenutni ili budući događaj poduzmu relevantne akcije za održanje mira i sigurnosti. Osnivanje NFIP-a pri policiji važno je zbog omogućavanja jednostavnije komunikacije jer samim tim i policija automatski dobiva sve potrebne informacije o događaju i nema gubitka vremena prilikom razmjene informacija. ${ }^{38}$

S druge pak strane, Vijeće Europske unije još je 1999. godine donijelo Rezoluciju o Priručniku za međunarodnu policijsku suradnju i mjere za sprečavanje i kontrolu nasilja i nemira povezanih s međunarodnim nogometnim utakmicama. ${ }^{39}$ Međutim, s obzirom na iskustva koja su se stekla 2012. godine na Europskom nogometnom prvenstvu i 2014. godine na Svjetskom nogometnom prvenstvu, pristupilo se dopunjavanju Rezolucije Vijeća o ažuriranom Priručniku s preporukama za međunarodnu policijsku suradnju te mjerama za sprečavanje i kontrolu nasilja i nemira povezanih s nogometnim utakmicama međunarodnog karaktera koje uključuju najmanje jednu državu članicu (dalje u tekstu: Rezolucija). ${ }^{40}$ To je napravljeno u suradnji 25 europskih zemalja ${ }^{41}$ koje su sudjelovale na paneuropskom projektu za osposobljavanje u području policijskog djelovanja na nogometnim utakmicama u razdoblju od 2011. do 2014. godine. Svrha je Rezolucije poboljšanje sigurnosti i zaštite na nogometnim utakmicama te povećanje međunarodne suradnje, a sadržajno je temeljena ponajviše na međunarodnoj policijskoj suradnji, te dosadašnjom praksom s naglaskom na integrirani pristup sigurnosti kroz multiagencijsko djelovanje. Rezolucijom se određuju glavna načela djelovanja i suradnje policije domaćina i gostujućih policijskih izaslanstava, ${ }^{42}$ troškovi i financiranje, pratnja, sustav gostujućih policijskih izaslanstava, jezik, akreditacije, ali i djelovanje na temelju bilateralnih dogovora sa zemljama u kojima nema NFIP-a. ${ }^{43}$ Pravovremena razmjena točnih informacija od najveće je važnosti u jačanju sigurnosti i zaštite te sprečavanju nasilja i nereda povezanih s nogometom.

38 Čl. 4. Odluke.

39 SL C 196, 13. VII. 1999., str. 1., vidi više na: https://eur-lex.europa.eu/legal-content/hr/ TXT/?uri=CELEX:32002G0124(01).

40 Rezolucija Vijeća o ažuriranom priručniku s preporukama za međunarodnu policijsku suradnju te mjerama za sprečavanje i kontrolu nasilja i nemira povezanih s nogometnim utakmicama međunarodnog karaktera koje uključuju najmanje jednu državu članicu (,Nogometni priručnik EU-a“), (2016/C 444/01), dostupna na: https:/eur-lex.europa.eu/legal-content/HR/TXT/?uri=CELEX\%3A32016G1129\%2801\%29.

41 Austrija, Belgija, Bugarska, Cipar, Danska, Estonija, Finska, Francuska, Grčka, Hrvatska, Irska, Italija, Litva, Nizozemska, Njemačka, Poljska, Portugal, Rumunjska, Španjolska, Švedska, Ujedinjena Kraljevina, Srbija, Švicarska, Turska i Ukrajina.

42 Rezolucija, str. 8.

43 Rezolucija, str. 9-14. 
Dr. sc. Damir Primorac i Marko Pilić: Sigurnost i zaštita na nogometnim utakmicama i ostalim.... Zbornik radova Pravnog fakulteta u Splitu, god. 56, 2/2019, str. 401.- 419.

Tablica 1. Potpisi i ratifikacije Konvencije br. $218^{44}$

\begin{tabular}{|c|c|c|c|}
\hline & POTPIS & RATIFIKACIJA & STUPILO NA SNAGU \\
\hline & \multicolumn{3}{|c|}{ DRŽAVE ČLANICE VIJEĆA EUROPE } \\
\hline \multicolumn{4}{|l|}{ Albanija } \\
\hline \multicolumn{4}{|l|}{ Andora } \\
\hline Armenija & $24 / 01 / 2018$ & & \\
\hline Austrija & $22 / 02 / 2017$ & & \\
\hline Azerbajdžan & $29 / 11 / 2016$ & $11 / 12 / 2018$ & $01 / 02 / 2019$ \\
\hline Belgija & $29 / 11 / 2016$ & & \\
\hline \multicolumn{4}{|c|}{ Bosna i Hercegovina } \\
\hline Bugarska & $03 / 07 / 2016$ & & \\
\hline \multicolumn{4}{|l|}{ Hrvatska } \\
\hline Cipar & $04 / 05 / 2017$ & & \\
\hline Češka & $30 / 11 / 2017$ & & \\
\hline \multicolumn{4}{|l|}{ Danska } \\
\hline \multicolumn{4}{|l|}{ Estonija } \\
\hline Finska & $20 / 12 / 2017$ & & \\
\hline Francuska & $03 / 07 / 2016$ & $06 / 02 / 2017$ & $01 / 11 / 2017$ \\
\hline Gruzija & $03 / 07 / 2016$ & & \\
\hline \multicolumn{4}{|l|}{ Njemačka } \\
\hline Grčka & $03 / 07 / 2016$ & & \\
\hline \multicolumn{4}{|l|}{ Mađarska } \\
\hline \multicolumn{4}{|l|}{ Island } \\
\hline \multicolumn{4}{|l|}{ Irska } \\
\hline Italija & $02 / 09 / 2016$ & & \\
\hline \multicolumn{4}{|l|}{ Latvija } \\
\hline \multicolumn{4}{|l|}{ Lihtenštajn } \\
\hline Litva & $03 / 07 / 2016$ & & \\
\hline Luksemburg & $29 / 11 / 2016$ & & \\
\hline \multicolumn{4}{|l|}{ Malta } \\
\hline Monaco & $03 / 07 / 2016$ & $02 / 03 / 2017$ & $01 / 11 / 2017$ \\
\hline Crna Gora & $03 / 07 / 2016$ & & \\
\hline Nizozemska & $03 / 07 / 2016$ & & \\
\hline Norveška & $29 / 11 / 2016$ & $11 / 12 / 2017$ & $01 / 02 / 2018$ \\
\hline Poljska & $29 / 11 / 2016$ & $18 / 09 / 2017$ & $01 / 11 / 2017$ \\
\hline Portugal & $03 / 07 / 2016$ & 19/06/2018 & $01 / 08 / 2018$ \\
\hline Moldavija & $03 / 07 / 2016$ & $10 / 01 / 2018$ & $01 / 03 / 2018$ \\
\hline Rumunjska & $29 / 11 / 2016$ & & \\
\hline Rusija & $03 / 07 / 2016$ & $03 / 10 / 2017$ & $01 / 12 / 2017$ \\
\hline \multicolumn{4}{|l|}{ San Marino } \\
\hline Srbija & & & \\
\hline
\end{tabular}

44 Vidjeti službenu internetsku stranicu Vijeća Europe, dostupno na: https://www.coe.int/en/web/ conventions/full-list/-/conventions/treaty/218/signatures?p_auth=f11YZeMj, pristupljeno 25. siječnja 2019. 
Dr. sc. Damir Primorac i Marko Pilić: Sigurnost i zaštita na nogometnim utakmicama i ostalim.... Zbornik radova Pravnog fakulteta u Splitu, god. 56, 2/2019, str. 401.- 419.

\begin{tabular}{|c|c|c|c|}
\hline \multicolumn{4}{|l|}{ Slovačka } \\
\hline Slovenija & $16 / 01 / 2018$ & & \\
\hline Španjolska & $23 / 05 / 2017$ & & \\
\hline Švedska & $10 / 01 / 2017$ & & \\
\hline Švicarska & $03 / 07 / 2016$ & & \\
\hline Makedonija & $03 / 07 / 2016$ & & \\
\hline Turska & $29 / 11 / 2016$ & & \\
\hline Ukrajina & $03 / 07 / 2016$ & & \\
\hline \multicolumn{4}{|l|}{$\begin{array}{l}\text { Ujedinjeno } \\
\text { Kraljevstvo }\end{array}$} \\
\hline \multicolumn{4}{|c|}{ DRŽAVE NEČLANICE VIJEĆA EUROPE } \\
\hline & POTPIS & RATIFIKACIJA & STUPILO NA SNAGU \\
\hline \multicolumn{4}{|l|}{ Bjelorusija } \\
\hline \multicolumn{4}{|l|}{ Sveta Stolica } \\
\hline \multicolumn{4}{|l|}{ Kazahstan } \\
\hline \multicolumn{4}{|l|}{ Maroko } \\
\hline \multicolumn{3}{|c|}{ UKUPAN BROJ POTPISA BEZ RATIFIKACIJE } & 22 \\
\hline \multicolumn{3}{|c|}{ UKUPAN BROJ RATIFIKACIJA } & 8 \\
\hline
\end{tabular}

U priloženoj tablici jasno se vidi koje su prve tri države ratificirale ovu konvenciju, ${ }^{45} \mathrm{~s}$ time da $\mathrm{RH}, \mathrm{s}$ današnjim danom, još uvijek nije postala stranka navedene konvencije. ${ }^{46}$

\subsection{SIGURNOST NA NOGOMETNIM UTAKMICAMA I OSTALIM ŠPORTSKIM PRIREDBAMA PREMA PRILOGU „A“ PREPORUKE STALNOG ODBORA O SIGURNOSTI, ZAŠTITI I USLUGAMA}

Stalna komisija Konvencije br. 120 usvojila je 18. lipnja 2015. godine dokument pod nazivom Preporuke (2015) Stalne komisije za sigurnost, zaštitu i usluge na nogometnim utakmicama i drugim športskim priredbama (dalje u tekstu: Preporuka) s ciljem da se utvrdi potreba o razvijanju, implementaciji integraciji multiagencijskog

45 Konvenciju br. 218 prve su ratificirale države Monaco, Poljska i Francuska čime je konvencija stupila na snagu.

46 Vlada Republike Hrvatske je 7. lipnja 2018. godine donijela prijedlog odluke o pokretanju postupka za sklapanje Konvencije Vijeća Europe o integriranom pristupu sigurnosti, zaštiti i uslugama na nogometnim utakmicama i drugim športskim priredbama u kojoj je prihvatila tekst Konvencije br. 218, a s obzirom na to da je Republika Hrvatska stranka Konvencije br. 120, potrebno je glavnom tajniku Vijeća Europe prethodno ili istovremeno s polaganjem isprave o ratifikaciji Konvencije br. 218. dostaviti i obavijest o otkazivanju Konvencije br. 120. Konvenciju br. 218 u ime Republike Hrvatske potpisuje potpredsjednica Vlade Republike Hrvatske i ministrica vanjskih i europskih poslova. 
pristupa sigurnosti, zaštiti i uslugama, posebno na razini nacionalnih i lokalnih koordinacijskih jedinica, ali i na razini međunarodne suradnje. ${ }^{47}$ Prvenstveno je bilo potrebno utvrditi značenje svakog pojma kao npr. sigurnost, zaštita i usluge, pa je tako u čl. 3. Konvencije br. 218 navedeno: a) ,sigurnosne mjere znače svaku mjeru osmišljenu i provedenu s glavnim ciljem zaštite zdravlja $i$ dobrobiti pojedinaca $i$ skupina koji prisustvuju, ili sudjeluju na nogometnoj utakmici ili drugoj športskoj priredbi, unutar ili izvan stadiona, ili koji žive ili rade u neposrednoj blizini priredbe; b) zaštitne mjere znače svaku mjeru osmišljenu i provedenu s glavnim ciljem sprečavanja, smanjenja rizika i/ili suprotstavljanja svakom nasilju ili drugoj kriminalnoj aktivnosti ili izgredu počinjenih u vezi s nogometnom utakmicom ili nekom drugom športskom priredbom, unutar ili izvan stadiona; c) uslužne mjere znače svaku mjeru osmišljenu i provedenu s glavnim ciljem da se pojedinci i skupine osjećaju ugodno, cijenjeno i dobrodošlo na nogometnoj utakmici ili drugoj športskoj priredbi, unutar ili izvan stadiona“.

Kako je već navedeno, Konvencija br. 218 temelji se upravo na ta tri ključna elementa koja su zamišljena da se „oslanjaju“ jedno na drugo odnosno da se provode kao tri međusobno zavisna elementa. U tom su kontekstu i donesena tri različita priloga Preporuke koja određuju mjere zasebno te je tako prilog „A“ najopširniji i postavlja smjernice za provođenje ostalih priloga (Prilog „B“ i Prilog „C“). Kada je u pitanju sigurnost na nogometnim utakmicama i ostalim športskim priredbama, nužno je postaviti ključna sigurnosna načela funkcioniranja koja nikada ne bi trebala biti kompromitirana. ${ }^{48}$ Preporuke za sigurnost na nogometnim utakmicama uključuju širok spektar pokrivenih tema kao što su lokalna i nacionalna koordinacija, nogometne institucije odgovorne za sigurnost, licenciranje stadiona te inspekcija istog, politički ekstremizam, infrastruktura, pristup utakmicama za osobe s invaliditetom pa čak i osposobljavanje zaduženih timova ljudi za sigurnost. Međutim, glavni naglasak stavljen je na sigurnost na stadionima što uključuje velik broj unaprijed definiranih preporuka i planova koje se savjetuju svim odgovornim tijelima i agencijama u postupku pružanja sigurnosti na stadionima i ostalim športskim objektima.

47 Preporuka (2015) Stalne komisije za sigurnost, zaštitu i usluge na nogometnim utakmicama i drugim športskim priredbama (eng. Recommendation Rec (2015) 1 of the Standing Committee on Safety, Security and Service at Football Matches and other Sports Events), dostupno na: https://rm.coe.int/ recommendation-rec-2015-1-of-the-standing-committee-on-safety-security/168072b9a2.

48 Ključni principi navedeni su u dokumentu Preporuka (2015) Stalne komisije za sigurnost, zaštitu i usluge na nogometnim utakmicama i drugim športskim priredbama - Prilog „A“ o sigurnosti - preporuke dobre prakse, str. 7-8., a to su: a) izbjegavanje nejasnoća i dvosmislenosti u procesu određivanja uloga $\mathrm{i}$ odgovornosti tj. za to određena osoba odgovorna je za sve sigurnosne i zaštitne procedure $u$ svim stadijima djelovanja, b) gledatelji ne smiju biti smješteni na nesigurnim građevinskim strukturama što uključuje i nefunkcionalne zaštitne sustave i opremu, c) odgovorna osoba treba se pobrinuti za razvoj $\mathrm{i}$ implementaciju zaštitnog sustava koji se povremeno provjerava i testira radi utvrđivanja procesa zaštite i sigurnosti, d) prenapučenost ili zbijanje na stadionima zabranjeno je, a odgovorna osoba zadužena je za osiguranje i izračun maksimalnog kapaciteta stadiona, e) rizici za gledatelje trebaju biti maksimalno smanjeni, a odgovorna osoba, u suradnji s policijom i drugim zaduženim agencijama, treba imati i pričuvne planove, kao što je i evakuacijski plan, testirane i efikasne. Više vidi na: https://www.coe.int/en/ web/sport/recommendation-2015-1. 
Tako se navodi da se zbog sigurnosti na stadionima treba voditi računa i o sljedećim elementima sigurnosti, a to su: razdvajajući sustavi koji pružaju sigurnost od drugih gledatelja, komunikacija između odgovornih tijela, kontrolne sobe, protuterorističko djelovanje, menadžment masa, korištenje dronova, pričuvni i hitni planovi kao i hitne evakuacije, standardizirani ulasci i izlasci sa stadiona, protupožarni planovi i procjena rizika, omogućavanje hrane i pića, vrijeđanje, rasizam i ostala diskriminatorna ponašanja, događaje koji se odvijaju u zatvorenim objektima, inspekcije i certificiranje objekata, određivanje maksimalnog broja gledatelja, plan djelovanja medicinskog osoblja, zaštita prostora određenog za igru, zabrana korištenja pirotehnike, vizualni komunikacijski sustavi za obavijest šire mase, uloge, funkcije, kompetencije i priprema osoba odgovornih za zaštitu, standardizacija sjedećih mjesta, područja na stadionima gdje se može stajati, kontrola prometa, VIP-ovi i druge akreditirane osobe..$^{49}$

U RH najčešće se susrećemo s izazovima korištenja pirotehnike, ne uzimajući u obzir infrastrukturne probleme koje imaju hrvatski klubovi zbog nedostatka financijskih sredstava. Pirotehnička sredstva predstavljaju opasnost za sigurnost ne samo onih koji ih koriste već i za druge gledatelje, predstavnike tijela sigurnosti i ostale dionike na stadionu, kao i za same igrače. Takva sredstva mogu uzrokovati kemijske reakcije koje rezultiraju stvaranjem velikih temperatura na samoj napravi, ali mogu rezultirati i dimom ili detonacijom. Rizici koje predstavljaju za sigurnost ostalih sudionika športskih priredbi nebrojeni su, počevši od dišnih problema, opasnosti od stvaranja vatre, a mogu uzrokovati i trenutni ili stalni gubitak sluha, kao i srčanu aritmiju. ${ }^{50}$ Prvi korak u sprečavanju korištenja pirotehničkih sredstava jest usredotočiti se na načine kojima su ta sredstva unesena na stadione, a to je najčešće: a) odvajanje dijelova pirotehničkog sredstva i spajanje nakon prolaska kroz standardne sigurnosne kontrole, b) unošenje naprava prije početka utakmice, za vrijeme dopuštenog pristupa za postavljanje transparenata, c) ostavljanje takvih naprava nekoliko dana prije početka utakmice u dijelovima stadiona koji pripadaju navijačima, d) korištenje tjelesnih šupljina za unos pirotehničkih naprava. ${ }^{51}$ Isto tako, počinitelji često koriste različite metode u pokušaju prikrivanja vlastitog identiteta, pa tako koriste transparente ili dim kako bi izbjegli snimanje lica na sigurnosnim kamerama, masovno nošenje jednake odjeće, skrivanje lica i sl.

U tom kontekstu, kroz ovaj dokument predlaže se da se ostale gledatelje i medije informira o svim mogućim načinima unosa pirotehničkih sredstava, i to preko klupskih internetskih stranica i foruma, preko stranica nacionalnih saveza, spikera na stadionima, televizije i sl. Naglašena je važnost suradnje agencija u pripremi i korištenju slika ili videozapisa u svrhu označavanja lokacije prijetnji na

49 Preporuke (2015) Stalne komisije za sigurnost, zaštitu i usluge na nogometnim utakmicama i ostalim športskim priredbama (eng. Recommendation Rec (2015) 1 of the Standing Committee on Safety, Security and Service at Football Matches and other Sports Events) - Prilog A o sigurnosti - Preporuke dobre prakse, str. 16-206. dostupno na: https://www.coe.int/en/web/sport/recommendation-2015-1.

50 Ibid, str. 123.

51 Ibid, str. 123. 
tribinama. ${ }^{52} \mathrm{~S}$ novom tehnologijom videonadzora, koja se već određeno vrijeme koristi u europskim prijestolnicama za detekciju terorista, sustav registrira opasnost i upozorava operatera koji potom reagira ovisno o potrebi. ${ }^{53}$ Nadalje, predlaže se da se osobe koje su bile ozlijeđene pirotehničkim sredstvom ili su ga koristile, potakne na suradnju u kampanji za povećanje svijesti o opasnostima za sigurnost koje predstavlja korištenje pirotehničkih sredstava. Isto tako, zakonodavni okvir mora predviđati sankcije za korištenje takvih sredstava, pogotovo ako dođe do ozljeđivanja drugih osoba, a prethodno su upozoreni da je korištenje pirotehnike zabranjeno. U Preporuci se spominju i uloga klubova i športske zajednice u provođenju njima dozvoljenih sankcija (ukidanje pretplata, zabrana dolaska na stadion i sl.), kao i procjena rizika i komunikacija s lokalnim sredinama u svrhu pribavljanja informacija o osobama za koje se smatra da bi mogle pokušati unijeti pirotehnička sredstva na stadion. Također, važno je postaviti primjer za društvo u cjelini te ne koristiti pirotehniku pri ceremonijalnim proslavama unutar samog stadiona.

\subsection{ZAŠTITA NA NOGOMETNIM UTAKMICAMA I OSTALIM ŠPORTSKIM PRIREDBAMA PREMA PRILOGU „B““ PREPORUKE STALNOG ODBORA O SIGURNOSTI, ZAŠTITI I USLUGAMA}

Preporuka u vezi sa zaštitom na nogometnim utakmicama i ostalim športskim priredbama usko je vezana i nadopunjuje se s preporukama o sigurnosti. ${ }^{54}$ Međutim, ovom Preporukom ne daje se konačno rješenje zbog postojanja širokog spektra ustavnih, sudskih, policijskih, kulturnih i povijesnih okolnosti te različitog karaktera potencijalnih incidenata koji su povezanih s nogometom, bilo da se isti odvijaju na području jedne ili više država. Isto tako, namjera je ove Preporuke osigurati niz dobrih rješenja koje države trebaju u potpunosti uzeti u obzir pri razvoju i pružanju strategije zaštite sudionika nogometne utakmice, ali i ostalih športskih priredbi. Sadržaj ovog priloga ${ }^{55}$ odnosi se ponajviše na ulogu policije u državnoj koordinaciji, ulogu Vlade, ulogu tijela progona, suradnju između policije, nogometnih organizacija i nogometnih klubova, shvaćanju dinamike među navijačima i rizika koji to donosi, ${ }^{56}$

52 Ibid, str. 124.

53 Podhraški, F., Tršinski, S., Kancir, K., „Prijedlog unapređenja rada policije uvođenjem videonadzora javnih prostora“, Policija i sigurnost, godina 17., broj 3-4, Zagreb, 2008., str. 251.

54 Preporuke (2015) Stalne komisije za sigurnost, zaštitu i usluge na nogometnim utakmicama i ostalim športskim priredbama - Prilog B o zaštiti - Preporuke dobre prakse.

55 Sekcija C Preporuke (2015) Stalne komisije za sigurnost, zaštitu i usluge na nogometnim utakmicama i ostalim športskim priredbama - Prilog B o zaštiti - Preporuke dobre prakse, str. 3-14.

56 Model dobre prakse odnosi se na djelovanje prije samog športskog događaja, u slučaju prve rizične situacije, povećavanjem rizika, smanjenjem tenzija (de-eskalacije) i nakon samog športskog događaja. Prije samog događaja potrebno je napraviti procjenu rizika te se treba uzeti u obzir: a) temeljna kultura grupe navijača koju treba nadzirati (npr. karakteristično ponašanje, motivacije i namjere); b) sve čimbenike koji bi mogli utjecati na rizik, npr. aktivnosti drugih skupina (kao što su pristaše drugog 
kategorizaciju rizičnosti pojedinih navijača, komunikaciju i suradnju s navijačima, ulogu NFIP-a, strategije u odnosu prema medijima, terorizam i ostale organizirane protupravne i kriminalne aktivnosti.

O važnosti uspostave NFIP-a već je napisano u samom tekstu Konvencije br. 218, s time da se NFIP u kontekstu ove Preporuke spominje s naglaskom na educiranost i kvalifikacije djelatnika pri NFIP-u. Također, djelatnici NFIP-a koordiniraju razmjenu informacija te nadgledaju i organiziraju rad i pripremu ostalih službenika s kojima surađuju. S obzirom na resornu lokaciju djelatnika NFIP-a koji djeluju pri policiji, nužno je da oni imaju pristup relevantnim policijskim bazama podataka jer iz tih baza podataka mogu izraditi profil pristaša određenog športskog kluba, kao $\mathrm{i}$ identificirati visokorizične grupe unutar tih istih pristaša i procijeniti potencijalni rizik cijele športske priredbe. Poučeni europskim iskustvom, utvrđeno je da je od ključne važnosti pružanje maksimalne potpore i resursa nacionalnim NFIP-ovima kako bi mogli upotrijebiti pravovremene i točne informacije u odgovarajućem trenutku. Komunikacije, razmjene informacija i medijske strategije također su važan dio ove Preporuke. U svrhu stvaranja sigurnog i zaštićenog okružja, ključno je korištenje svih medija u širenju postojećih informacija (što ne isključuje i obraćanje javnosti za pomoć) lokalnim zajednicama o postupanju policije i ostalih agencija tijekom športske priredbe. ${ }^{57}$ Slijedom toga, u Sekciji R priloga „B“ Preporuke preporučuje se da glasnogovornici odgovornih nacionalnih tijela i lokalne policije blisko surađuju sa svojim kolegama u vladi, lokalnim vlastima, nogometnim tijelima i drugim partnerskim agencijama u pripremi i provedbi sveobuhvatne komunikacijske strategije. ${ }^{58}$

\footnotetext{
kluba; c) bilo koje okolnosti koje bi mogle utjecati na ponašanje ili rizik koji predstavljaju oni navijači ili skupine za koje se smatra da su rizik za javni red. Kod prve rizične situacije preporuča se: a) policija bi se trebala uključiti u visoku razinu pozitivne osobne interakcije s navijačima (neagresivni stav, smiješak, raspoređivanje u parovima ili u malim grupama u standardnoj uniformi, raspršeni širom gužve itd.); b) gdje jezik nije prepreka, službenici bi trebali pokušati komunicirati s navijačima kako bi prikupili informacije o njihovom namjerama, zabrinutostima, osjećajima i svim drugim pitanjima relevantnima za njihovo ponašanje; c) interventne jedinice trebaju se locirati na diskretnim mjestima, osim ako situacija ne odredi da je potrebna snažnija intervencija. Kada se utvrde okolnosti koje predstavljaju rizik, važno je: a) komunicirati s onima koji predstavljaju rizik pa izazivaju potencijalnu policijsku intervenciju; b) gdje incident uključuje gostujuće navijače, policijska procjena trebala bi biti potvrđena od strane policijske delegirane na dijelu s gostujućim navijačima. Nakon smirivanja situacije, sve agencije i odgovorna tijela vraćaju se na svoje prvotne pozicije. Zaključno, nakon samog športskog događaja, potrebno je provesti detaljan izvještaj svih relevantnih informacija i događaja (npr. kvaliteta informacija primljenih prije $\mathrm{i}$ tijekom događaja, ponašanje i upravljanje navijačima, policijska taktika i sl.).

57 Informacije o policijskom postupanju daju se u cilju odvraćanja od nedoličnog ponašanja (potencijalnim počiniteljima daje se do znanja da su nadležna tijela spremna na reakciju) ili kontroliranja već nastalog nedoličnog ponašanja. Logika ovog postupka opravdava se tezom: „Ako navedemo na što smo sve spremni, onda kontroliramo i elemente koje nismo naveli“ (op. a.).

58 Sekcija R Preporuke (2015) Stalne komisije za sigurnost, zaštitu i usluge na nogometnim utakmicama i ostalim športskim priredbama - Prilog B o zaštiti - Preporuke dobre prakse, str. 14.
} 


\subsection{USLUGE NA NOGOMETNIM UTAKMICAMA I OSTALIM ŠPORTSKIM PRIREDBAMA PREMA PRILOGU „C“ PREPORUKE STALNOG ODBORA O SIGURNOSTI, ZAŠTITI I USLUGAMA}

Prilog „C“ Preporuke u vezi s uslugama na nogometnim utakmicama i ostalim športskim priredbama usko je vezan i nadopunjuje se s prilozima za sigurnost $\mathrm{i}$ zaštitu. ${ }^{59}$ Ovim prilogom pokrivaju se svi aspekti nogometnog iskustva, unutar i izvan stadiona, ali i prije, za vrijeme i poslije događaja kada je u pitanju pružanje usluga. Koncept usluge na nogometnim stadionima usredotočuje se na ključna načela učinkovite komunikacije i usvajanje mjera usmjerenih na sigurnost, zaštitu i dobrobit navijača. Također, takva ideja odnosi se i na inicijative koje su rješenja na dulje vrijeme i kao takve su sveobuhvatnije, a uključuju društvene projekte osmišljene za stvaranje osjećaja partnerstva i suradnje između javnih i privatnih agencija uključenih u događaje vezane za nogomet, a to se odnosi i na suradnju s navijačima.

Navijačka kultura pruža model ponašanja za nadolazeće generacije i nužnost je ostvariti pozitivnu kulturu navijanja kao što su to uspjele skandinavske zemlje. ${ }^{60}$ Skandinavske zemlje prenose i drugačiji pogled na sigurnost, zaštitu i usluge, a to je kroz sustav planiranja urbane prevencije kriminaliteta, gdje već nekoliko stadija prije izgradnje samog športskog objekta donose građevinska rješenja koja utječu na sigurnost, ali vode brigu i o subjektivnoj percepciji i osjećaju sigurnosti kako posjetitelja tako i onih koji stanuju u blizini. ${ }^{6}{ }^{1}$ Sto se tiče sigurnosti, europsko iskustvo dokazuje da navijači pozitivno reagiraju kada se osjećaju dobrodošlo. ${ }^{62}$ Ukratko, veća je vjerojatnost da će navijači tretirani s poštovanjem odgovoriti na isti način. To je osobito slučaj kada se operacije upravljanja masama (crowd management) percipiraju kao prikladne i proporcionalne, a ne diskriminatorne. U prijašnja dva priloga često se susreće pojam suradnje između lokalnih, nacionalnih i međunarodnih tijela u zaštiti, sigurnosti i pružanju usluga na nogometnim utakmicama, što ni u ovom dijelu nije izostavljeno. Međutim, u ovom prilogu naglasak je stavljen na interakciju nadležnih tijela s navijačima i lokalnom zajednicom u zajedničkom cilju nadgledanja i pružanja kvalitetne usluge. Iz tog razloga nužno je shvatiti dinamiku i rizike u ostvarivanju dijaloga s navijačima te osposobiti službenike koji će biti spona između navijača i nadležnih tijela. U tom kontekstu važna je i medijska slika koja može biti od velike koristi na način da prezentira i hvali one najbolje suradnje,

59 Preporuke (2015) Stalne komisije za sigurnost, zaštitu i usluge na nogometnim utakmicama i ostalim športskim priredbama - Prilog C o uslugama - Preporuke dobre prakse.

60 Comeron, M., The prevention of violence in sport, Council of Europe, str. 17.

${ }_{61}$ Petković, Ž., „Prevencija kriminaliteta na športskim stadionima kroz planiranje okoliša“, Policija i sigurnost, godina 18., broj 3, Zagreb, 2009., str. 366.

62 Dugi redovi za ulazak izazivaju nervozu i nestrpljenje, nepotrebne zapljene stvari pokazuju nepoštovanje, nečisti dijelovi stadiona koji su predviđeni za navijače ukazuju na lijenost $i$ manjak radne etike, ograde, žice i kavezi utječu na ponašanje navijača i stvaranje neprijateljskog ozračja prema „domaćinima“ i službenom osoblju, slaba vidljivost samog športskog događaja uzrokuje pretjerano pomicanje mase ljudi ili stajanje na mjestima na kojima je predviđeno sjedenje. 
a ne ističe samo loše trenutke koje se dogode na stadionima i koji mogu potencirati stvaranje jaza između navijača i tijela zaduženih za njihovu sigurnost, zaštitu i ostale usluge. Samim tim postavlja se cilj stvaranja otvorenog i transparentnog dijaloga s navijačima u pogledu kratkoročnih i dugoročnih ciljeva. Da bi se to ostvarilo, važno je uspostaviti strukture dijaloga navijača na međunarodnoj, nacionalnoj i lokalnoj razini, te u sve to uključiti: skupine navijača, inicijative usmjerene na navijače, projekte za navijače, službenike za suradnju navijača i nadležnih tijela, gradske i općinske vlasti, policiju, organizacije odgovorne za prijevoz, nogometne klubove, nacionalnu nogometnu organizaciju te službenike za sigurnost stadiona. ${ }^{63}$ Sukladno europskom iskustvu, okolina u kojoj se navijač osjeća sigurno, zaštićeno i dobrodošlo, potiče i njega na pokazivanje poštovanja prema službenom osoblju i prostorijama na stadionu, potiče ga na zaključak da su pravila koja se provode smišljena i za njegovo dobro. Naposljetku i sam smanjuje toleranciju prema nasilnim, diskriminatornim i protupravnim postupcima onih navijača koji takvo ponašanje prakticiraju.

\section{ZAKLJUČAK}

Važnost Konvencije br. 218 prije svega se ogleda u potpori koju je dobila od država članica radi suzbijanja nasilja na športskim priredbama, ne samo na nacionalnoj razini, već i na priredbama s međunarodnim elementom. Kao takva, Konvencija br. 218 usklađena je s politikom djelovanja Europske unije po pitanju stvaranja sigurnosti, zaštite i usluga u sportu, ali i kao dio politike suradnje država članica s trećim zemljama u području sporta i obrazovanja. Glavni cilj ove konvencije jest pružanje sigurnosti, zaštite i usluga ponajviše na nogometnim utakmicama, ali i na ostalim športskim priredbama, što samo po sebi zahtijeva i integraciju multiagencijskog pristupa u osiguranju navedenih ciljeva, kao i aktivni pristup i suradnju s lokalnim, nacionalnim i međunarodnim tijelima. Za takvu suradnju nužan je i NFIP - izravne i jedinstvene kontaktne točke za razmjenu općih informacija u vezi s nogometnim utakmicama međunarodnog značaja koje će jednostavnije koordinirati i organizirati provedbu međunarodne policijske suradnje.

Važno je naglasiti kako je u RH danom 1. kolovoza 2006. godine ustrojen i započeo s radom Odsjek za sprečavanje nereda na športskim natjecanjima unutar Odjela za javni red Uprave policije Ravnateljstva policije MUP-a RH, kao hrvatski NFIP. Prvi pravi test bila je nogometna utakmica s Engleskom 11. listopada 2006. godine kada su se uvidjele sve prednosti ovakvog sustava pa je uslijed toga potpisana suradnja s engleskim NFIP-om. Sve je to rezultiralo suradnjom u poduzimanju preventivnih mjera prije, za vrijeme i nakon same utakmice, ali i pružanjem pomoći engleskog izaslanstva, kao i dolaskom posebnog engleskog policijskog tima sa savjetodavnom

63 Dodatak prilogu 1 - Dijalog i komunikacija s navijačima - Preporuke (2015) Stalne komisije za sigurnost, zaštitu i usluge na nogometnim utakmicama i ostalim športskim priredbama - Prilog C o uslugama - Preporuke dobre prakse, str. 13. 
i operativnom ulogom. ${ }^{64}$ Isto tako, da bi se osigurale sigurnost, zaštita i kvalitetna usluga na nogometnim utakmicama i ostalim športskim priredbama, od ključne je važnosti uspostaviti norme djelovanja i aplicirati ih sukladno mogućnostima. U tom kontekstu donesena su tri, međusobno povezana priloga kojima se izlažu preporuke u postupanju prema elementima sigurnosti, zaštite i usluga na nogometnim utakmicama i drugim športskim priredbama.

\section{LITERATURA}

1. Bodin, D., Robene, L., Heas, S., Sport i nasilje u Europi, Knjiga trgovina d.o.o., Zagreb, 2007.

2. Comeron, M., The prevention of violence in sport, Council of Europe, Strasbourg, 2002.

3. Europska konvencija o nasilju i nedoličnom ponašanju gledatelja na športskim priredbama, posebice na nogometnim utakmicama, CETS br. 120, Strasbourg, 1985.

4. Jovašević, D., Batrićević, A., „Suppression of spectator violence at sports events“, Facta Universitatis, Physical Education \& Sport, 11 (3), Beograd, 2013.

5. Konvencije Vijeća Europe o integriranom pristupu sigurnosti, zaštiti i uslugama na nogometnim utakmicama i drugim športskim priredbama, CETS br. 218, Saint-Denise, 2016.

6. Margetić, M., Borovec K., „Zakon o sprječavanju nereda na športskim natjecanjima - preventivne i represivne mjere sudova i policije“" Hrvatski ljetopis za kazneno pravo i praksu, vol. 22, broj 2, Zagreb, 2015.

7. Nimac, K., „Sprječavanje nereda na športskim natjecanjima - zakonska regulativa u Republici Hrvatskoj i nekim europskim zemljama“, Zbornik radova Veleučilišta u Šibeniku, No. 3-4, Šibenik, 2016.

8. Odluka Vijeća od 25. travnja 2002. o sigurnosti u vezi s nogometnim utakmicama s međunarodnim elementom (2002/348/PUP).

9. Petković, Ž., „Prevencija kriminaliteta na športskim stadionima kroz planiranje okoliša“, Policija i sigurnost, godina 18., broj 3, Zagreb, 2009.

10. Podhraški, F., Tršinski, S., Kancir, K., „Prijedlog unapređenja rada policije uvođenjem videonadzora javnih prostora“, Policija i sigurnost, godina 17., broj 3-4., Zagreb, 2008.

11. Prijedlog Odluke Vijeća o ovlašćivanju država članica da postanu stranke, u interesu Europske unije, Konvencije Vijeća Europe o integriranom pristupu sigurnosti, zaštiti i uslugama na nogometnim utakmicama i drugim športskim priredbama (CETS. br. 218), Bruxelles, 2018.

12. Primorac, D., Duvnjak, Ž., Roso, S., „Neki aspekti prekršaja prema zakonu o sprječavanju nereda na športskim natjecanjima“, Zbornik radova Pravnog fakulteta u Splitu, god. 47, 2, Split, 2010.

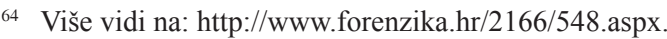


13. Primorac, D., Konjić, Z., Blaće, K., „Kaznena djela u zakonu o sprječavanju nereda na športskim natjecanjima s osvrtom na mjere opreza prema zakonu o kaznenom postupku“, Zbornik radova Pravnog fakulteta u Splitu, god. 48, 4, Split, 2011.

14. Recommendation Rec (2015) 1 of the Standing Committee on Safety, Security and Service at Football Matches and other Sports Events - ANNEX A on Safety - Recommended Good Practices.

15. Recommendation Rec (2015) 1 of the Standing Committee on Safety, Security and Service at Football Matches and other Sports Events - ANNEX B on Security - Recommended Good Practices.

16. Recommendation Rec (2015) 1 of the Standing Committee on Safety, Security and Service at Football Matches and other Sports Events - ANNEX C on Service - Recommended Good Practices.

17. Rezolucija Vijeća o ažuriranom priručniku s preporukama za međunarodnu policijsku suradnju te mjerama za sprječavanje i kontrolu nasilja i nemira povezanih s nogometnim utakmicama međunarodnog karaktera koje uključuju najmanje jednu državu članicu (,Nogometni priručnik EU-a“), (2016/C 444/01).

18. Šuput, D., ,Pravni okvir koji uređuje borbu protiv nasilja na sportskim priredbama u evropskim državama“, Strani pravni život, Beograd, 2010.

19. Tsoukala A., Football Hooliganism in Europe - Security and Civil Liberties in the Balance, Palgrave Macmillan, England, 2009.

20. Ugovor o funkcioniranju Europske unije, dostupno na: http://www.mvep.hr/ custompages/static/hrv/files/pregovori/111221-lisabonski-prociscena.pdf.

21. Zakon o sprječavanju nereda na športskim natjecanjima (NN br. 117/03, 71/06, 43/09, 34/11).

22. https://sport.hrt.hr/465474/izbori/meusobna-tucnjava-bbb-a-ispred-stadiona-ubelgiji

23. http://www.sirc.org/publik/fvexec.html\#_VPID_8

24. https://www.sportskeeda.com/cricket/cricket-history-the-sydney-riot-1879

25. http://dailyiowan.lib.uiowa.edu/DI/1995/di1995-02-08.pdf

26. https://www.legislation.gov.uk/ukpga/1989/37

27. https://www.coe.int/en/web/conventions/full-list/-/conventions/treaty/218/ signatures?p_auth=f11YZeMj 


\section{SAFETY AND SECURITY AT FOOTBALL MATCHES AND OTHER SPORTS EVENTS, ACCORDING TO THE SOLUTIONS OF COUNCIL OF EUROPE'S CONVENTION CETS NO. 218}

Encouraged by the violent behavior of certain football fans in Brussels at Heysel Stadium on 29 May 1985, the Council of Europe European Convention on Spectator Violence and Misbehaviour at Sports Events and in particular at Football Matches i.e. Convention no. 120 (CETS no. 120) which entered into force on 1 November 1985. Convention no. 120 retained its original features until 2013 when the Council of Ministers concluded that it was outdated and that it was not in line with the experience gained since the entry into force. Consequently, the Standing Committee decided to draft a new text of the Convention and it resulted with Convention no. 218 (CETS no. 218) i.e. Council of Europe's Convention on an Integrated Safety, Security, and Service Approach at Football Matches and Other Sports Events. Safety measures, security measures and measures in the area of services, as a key part of Convention No. 218, aim to create a safe and secure environment at all sports events. An integrated approach to safety and security requires coordination at the international, national and local levels, and emphasizes the importance of effective co-operation with the police, emergency services and other partners not only in terms of guaranteeing physical security but also in preventing discriminatory and racist behavior. The importance of establishing a national football information point has also been established as a key mediator in the exchange of information on football matches with an international character as well as for the international cooperation of state bodies essential for the safety and security at football matches. Reasons for the emergence of Convention no. 218 is not only in the prevention of violent behavior at sporting events and in improving safety and security, but also in further development and better coordination of international cooperation in the prosecution of perpetrators of such inappropriate acts.

Key words: safety, security, sports events, violent behavior 